\title{
AGENCY THEORY PROBLEMS BEHIND THE FALL OF SHOPPING CENTERS
}

The present article assesses agency theory related problems contributing to the fall of shopping centers. The negative effects of the financial and economic downturn started in 2008 were accentuated in emerging markets like Romania. Several shopping centers were closed or sold through bankruptcy proceedings or forced execution. These failed shopping centers, 10 in number, were selected in order to assess agency theory problems contributing to the failure of shopping centers; as research method qualitative multiple cases-studies is used. Results suggest, that in all of the cases the risk adverse behavior of the External Investor-Principal, lead to risk sharing problems and subsequently to the fall of the shopping centers. In some of the cases Moral Hazard (lack of Developer-Agent's know-how and experience) as well as Adverse Selection problems could be identified. The novelty of the topic for the shopping center industry and the empirical evidences confer a significant academic and practical value to the present article.

Keywords: agency theory, financial crisis, shopping centers

The financial and economic crisis starting in 2008, has marked the life of several real estate project and investment worldwide. This negative effect got more intensive in emerging markets (Sliupas - Simanaviciene, 2010; Golob et al., 2012; Cocconcelli - Medda, 2013) and Romania was of no exception. Therefore in the last years, several shopping centers were closed, the delivery of some of them were postponed; and quite some of them changed owners either through bankruptcy, public tender, forced execution or in luckier cases through direct negotiations. It would be myopic to state that the fall of these shopping centers was amongst others not influenced by an inappropriate location, by the overestimated demand and purchasing power or by the neglected competition. This is especially true in case of the closed shopping centers. But shopping centers in operation with an occupancy rate of ca. $80 \%$ also became endangered. As Burr (2011: p. 7.) states "the decline of the commercial real estate and commercial real estate mortgage markets started later and was arguably more of a result than a cause of the recession." In their cases the problem started from the pressure in repaying bank loans and credits contracted during the development of the shopping centers, while "stricter underwriting guidelines and declining asset values have made the refinancing of commercial real estate assets very challenging" (Blurr, 2011: p. 7.). External Investors (Lenders) lost their patience, trust and confidence and started own measures for debt recovery. These indicate a rupture in the cooperation of shopping center industry actors and signal agency theory related problems, especially in terms of risk sharing. According to Eisenhardt (1989: p. 59.) "overall, the domain of agency theory is relationships that mirror the basic agency structure of a principal and an agent who are engaged in a cooperative behavior, but have differing goals and differing attitudes towards risk." The institutional background of the shopping center industry requires a strong cooperative behavior between Investors, Developers and External Investors (Lenders), although each of them has different goals and attitudes towards risk. Therefore the institutional background of the shopping industry urges the use of agency perspectives in the analysis of these failures, ten in number.

The article is consisting of seven major chapters. After the introduction, we discuss the main remarks in the relevant literature and formulate the theoretical background of the shopping center industry specific principal-agent problems. We formulate the research questions and develop some propositions, which will 
be tested by the analysis of 10 shopping center failure in Romania trough the method of multiple-cases study. The logic behind the adequacy of the chosen research method is explained in the fifth chapter. We follow with the detailed description of the cases and their analysis through the lens of the 3 scenarios from the previously formulated principal-agent relationships. The pattern matching and cross-cases synthesis provide results in order to accept or reject the propositions. The last chapter summarizes the conclusions and provides recommendations for future researches.

\section{Literature review}

The current financial crisis started due to a bubble in asset prices during the fall of 2008, is not the first one and certainly not going to be neither the last one. Allen - Gale (2000: p. 236.) recall as historical examples "the Dutch Tulipmania, the South Sea bubble in England, the Mississippi bubble in France, the Great Crash of 1929" and more close examples are the rocketing rise of real estate and stock prices at the late 1980s in Japan and their subsequent collapse in the beginning of the 1990s or the dot.com crash in 2000 . All these crises triggered the same consequences on real estates: high vacancy rates, drastic fall of rental prices, the foreclosure of mortgages with the so-called initial owners wiped out and lenders overtaking properties in the pursuit of investment protection (Wheelock, 1931). The seeds of these bubbles and crises were analyzed by several researchers (Allen - Gorton, 1993; Allen - Gale, 2000; Sliupas - Simanaviciene, 2010; Fanning et al., 2011; Acharya - Naqvi, 2012), who all found that the bubbles in asset prices are due to financial liberalization with increase in lending and abundantly available cheap capital during of which transactional purchase prices shift away from the fundamental values of the assets. The bubbles burst in the moment market actors reach to the point where their future price expectations turns from increase to decrease. Sliupas - Simanaviciene (2010) found evidence that the housing price inflation in Lithuania was very strongly influenced by the speculative housing price expectation with ca. $50 \%$ in comparison with GDP (PPP) per capita, which influence countered only for $18,25 \%$. When the speculative price expectancy starts to fall, asset prices indeed fall drastically within a short period of time and are followed by a longer wave of defaults of firms who borrowed money to buy assets at inflated peak prices, of banking institutions and foreign exchange rates. If we look deeper, we'll find that the increase in lending is actually the result of agency problems between investors, banks, lenders and portfolio managers (Allen - Gorton, 1993), of risk shifting or asset substitution in cases of borrowing for pre-existing assets, of expectations in future credit expansions (Allen - Gale, 2000) and of agency problems within banks through asymmetric information in the banking system (Mishkin, 1997) and moral hazard through bonus awarded risk-taking behavior, where bonuses are distributed based on the volume of financed assets and thus leading to "excessive lending and asset price bubbles" (Acharya - Naqvi, 2012: p. 350.). These agency problems are the roots of asset price bubbles, but they become visible only once the bubble bursts and during the long wave of defaults. Researchers than focus on flattening measures like land tax use (Cocconcelli - Medda, 2013) or on efficient organizational structures like UPREIT (Umbrella Partnership Real Estate Investment Trust) (Ebrahim - Mathur, 2013) or on banking operations of evergreening (shift from high-quality borrowers to low-quality borrowers) and writing off NPL's (nonperforming loans) (Watanabe, 2010). From all these, actually UPREIT's might represent a preventive solution to alleviate moral hazard in CDO's and are "designed to mitigate transaction costs [...], administrative costs, bankruptcy costs, illiquidity costs [...] and to minimize endogenous agency costs of debt" (Ebrahim - Mathur, 2013: p. 302.).

The present article analyses the effects of the crisis on a very specific part of the real estate industry, more precisely on the shopping centers, in contrast to previous studies which were focused on the residential real estate market (Sliupas - Simanaviciene, 2010; Golob et al., 2012; Cocconcelli - Medda, 2013). Shopping centers are special products of the real estate industry developed with the pursuit of achieving profit through the so-called "exit" or selling of the center, which can have a form of forward purchase or after completion. Shopping centers are also distinct real estate projects which during their development undergo project financing, financing of pre-existent assets. For the purpose of effective project financing the financed projects are allocated to distinct project companies, the so called "special purpose vehicles" (SPV). According to Jensen (1983: p. 361.) SPV's are agents of others which aid "avoiding personal liability for loans to finance the acquisition, construction, improvement, or refinancing of a business venture and protecting transferred property from attachment by, or from the claims of, creditors of individual investors". The loans are to be repaid from the project company's cash flow during the operation of the project, with limited warranty 
from the developer's side and thus direct risk from the lender's or investor's side. These projects 'tap the financial markets in two main ways. First, project sponsors or third-party investors (usually specialized investment funds) issue equity" in the form of ordinary shares or subordinate debt, a type of quasi-equity which is also called mezzanine capital. [...] Second, the senior debt in $80 \%$ of the cases is bank debt "syndicated" on the international financial markets" (Lyonnet du Moutier, 2010: p. 128-129.). Due to this two-fold project financing, the debt-to-equity ratio in SPV's are quite high, usually between $60-90 \%$ of the total investment. The revenue risk is borne by external investors (financing banks. lenders) and investors. Therefore external investors and lenders try to secure their investments and preserve their interests by a series of complex contractual schemes, through which they acquire ownership right surrogates (Flaskár, 2011) over on a longer term and tackles the agency problems contributing to the fall of these shopping centers. Despite the fact that the fall of shopping centers was more a result of, than a cause to the financial and economic crisis beginning in 2008 (Blurr, 2011), the thus started long wave of defaults shed light on some agency problems within the shopping center industry. The agency theory related problems will be assessed alongside of other complementary organizational economics theories such as transaction costs theory (Williamson, 1991) and property rights theory (Kim - Mahoney, 2005). Organizational economics ,is grounded on economic model of human behavior which assumes that individual's behavior is opportunistic, self-serving and motivated by satisfying personal goals" (Podrug et al., 2010: p. 1227.) and for a better overview on organizational economics theories we rely on Table 1 summarizing the main aspects of these theories.

Overview of Organization Economics Theories

\begin{tabular}{|c|c|c|c|}
\hline Criteria & Agency Theory & Property Rights Theory & Transaction Costs Theory \\
\hline Key Idea & $\begin{array}{l}\text { Principal-agent relationships should } \\
\text { reflect efficient organization of } \\
\text { information and risk-bearing costs. }\end{array}$ & $\begin{array}{l}\text { Partitioning of property rights } \\
\text { and efficient reallocation of } \\
\text { them amongst contracting } \\
\text { parties. }\end{array}$ & $\begin{array}{l}\text { Transaction contracts should } \\
\text { reflect efficiency by minimizing } \\
\text { transaction costs for both } \\
\text { contracting parties. }\end{array}$ \\
\hline Unit of analysis & $\begin{array}{l}\text { Contract between principal and } \\
\text { agent - behavior vs. outcome based } \\
\text { remuneration. }\end{array}$ & $\begin{array}{c}\text { A special contractual situation } \\
\text { - a configuration of property } \\
\text { rights (e.g. an institutional } \\
\text { arrangement) }\end{array}$ & $\begin{array}{l}\text { Transaction contract - various } \\
\text { types of asset specificity. }\end{array}$ \\
\hline Contracting problems & $\begin{array}{l}\text { Moral hazard. } \\
\text { Adverse selection. } \\
\text { Risk sharing. }\end{array}$ & $\begin{array}{c}\text { Externalities. } \\
\text { Rent seeking. } \\
\text { Vested interests and rights. } \\
\text { Week appropriability. }\end{array}$ & $\begin{array}{l}\text { Maladaptation. } \\
\text { Adverse selection. } \\
\text { Holdup problems. }\end{array}$ \\
\hline Human Assumptions & \multicolumn{3}{|c|}{ Self-interest, bounded rationality and risk aversion. } \\
\hline Organizational assumptions & \multicolumn{3}{|c|}{ Partial goal conflict, efficiency and information asymmetry. } \\
\hline Market assumptions & \multicolumn{3}{|c|}{ Un-observability, uncertainty and asset specificity. } \\
\hline
\end{tabular}

Source: based on Eisenhardt (1989: pg. 59.) and Kim - Mahoney (2005: p. 231.)

the financed asset and the project company: mortgage on asset, pledge on shares, mortgage on receivables, insurances and accounts and rights of first refusal on transfer of assets or shares of the SPV. According to Shah - Thakor (1987) the high debt-to-equity ratio in project financing is sustained by reduced information asymmetry due to the usage of SPV's. Nevertheless, the high debt-to-equity ratio inherently suggests that this field is based on highly opportunistic behavior and therefore provides an interesting context for agency theory analysis.

In the present article, the view of analysis over the effects of the crisis for the shopping center industry is
Organizational economics theories, however are focusing on different contractual aspects, are all designed to complementarily explain and predict the behavior of certain actors in a specific field or market taking into consideration the complexity of relationships. The present article builds on the positivist stream of agency theory describing the shopping center industry from an agency theory approach, identifying agency problems between actors of this field. From this point of view, the present article relies on studies like of Jensen - Meckling (1976), Fama (1980) and Argawal - Mandelker (1987) which are focusing on agency problems within the relationship of shareholders, stakeholders 
Distribution of main activities and agency theory problems when a single corporation (group) plays the role of investor, developer and center manager

\begin{tabular}{|c|c|c|c|c|c|c|c|c|}
\hline Market Actors & Ownership & Financing & Development & Lease & Operation & Risk & Information & Control \\
\hline Investors & $\mathrm{X}$ & $\mathrm{X}$ & & & & $\mathrm{X}$ & & \\
\hline Developers & $\mathrm{X}$ & $\mathrm{X}$ & $\mathrm{X}$ & $\mathrm{X}$ & $\mathrm{X}$ & $\mathrm{X}$ & $\mathrm{X}$ & $\mathrm{X}$ \\
\hline Center Managers & $\mathrm{X}$ & $\mathrm{X}$ & & $\mathrm{X}$ & $\mathrm{X}$ & $\mathrm{X}$ & $\mathrm{X}$ & $\mathrm{X}$ \\
\hline
\end{tabular}

Source: own observation

Table 3

Distribution of main activities and agency theory problems when distinct corporations (groups) play the role of investor, developer and center manager

\begin{tabular}{|c|c|c|c|c|c|c|c|c|}
\hline Market Actors & Ownership & Financing & Development & Lease & Operation & Risk & Information & Control \\
\hline Investors & $\mathrm{X}$ & $\mathrm{X}$ & & & & $\mathrm{X}$ & & \\
\hline Developers & & & $\mathrm{X}$ & $\mathrm{X}$ & & & $\mathrm{X}$ & $\mathrm{X}$ \\
\hline Center Managers & & & & $\mathrm{X}$ & $\mathrm{X}$ & & $\mathrm{X}$ & $\mathrm{X}$ \\
\hline
\end{tabular}

Source: own observation

Distribution of main activities and

Table 4

agency theory problems when separate corporations (groups) play the role of developer and center manager, while both play the role of investorsr

\begin{tabular}{|c|c|c|c|c|c|c|c|c|}
\hline Market Actors & Ownership & Financing & Development & Lease & Operation & Risk & Information & Control \\
\hline Investors & & $\mathrm{X}$ & & & $\mathrm{X}$ & $\mathrm{X}$ & & \\
\hline Developers & $\mathrm{X}$ & $\mathrm{X}$ & $\mathrm{X}$ & $\mathrm{X}$ & & $\mathrm{X}$ & $\mathrm{X}$ & $\mathrm{X}$ \\
\hline Center Managers & & & & $\mathrm{X}$ & $\mathrm{X}$ & & $\mathrm{X}$ & \\
\hline
\end{tabular}

Source: own observation

and managers; on studies of Allen - Gorton (1993), Allen - Gale (2000) assessing risk sharing agency problems between investors and portfolio managers, and between lenders and borrowers with limited liability; on the study of Levitt - Syverson (2008) detailing information asymmetry agency problems between real estate agents and their clients during transactions; and on the study of Acharya - Naqvi (2012) about moral hazard agency problems within banks. The novelty of the article is however that it analyses agency problems of the shopping center industry, which hasn't been assessed previously, as most studies focus on the residential market.

Another novelty of the present article is in its research method, analyzing these agency problems in multiple cases and on a longer term from their occurrence till their solution. Usually studies focusing on agency problems provide solutions only on a theoretical level, recommending mathematical functions or special contractual constructs. In contrast to most of those studies, the present article focuses on micro level cases instead of a macro-level approach and presents empirical solutions.

\section{Theoretical background}

\section{Principal-Agent Relationships in the Shopping Center Industry}

In the shopping center industry agency theory related problems have two roots: ownership and invested capital. The occurrence and deepening of the agency theory related problems depends quite much on who owns the respective SPV incorporating the shopping center, and on what kind of relationship exists between the center owner and the investors, external lenders, developers and center managers. The other factor in the evolution of agency theory related problems is the project financing, the invested capital, i.e. from whose capital will the shopping center be developed. Ownership and financing structures have been in the focus of agency theory related research of organizations since the works of Jensen - Meckling (1976), Fama (1980) and Argawal - Mandelker (1987). Nevertheless, the present article is pioneering in applying these concepts to the shopping center industry.

The principal-agent theory related problems are characteristic especially for the relationships between center managers, developers and investors. Shopping 
Principal-Agent Relationship when the role of the investor, developer and center manager is played by one corporate group

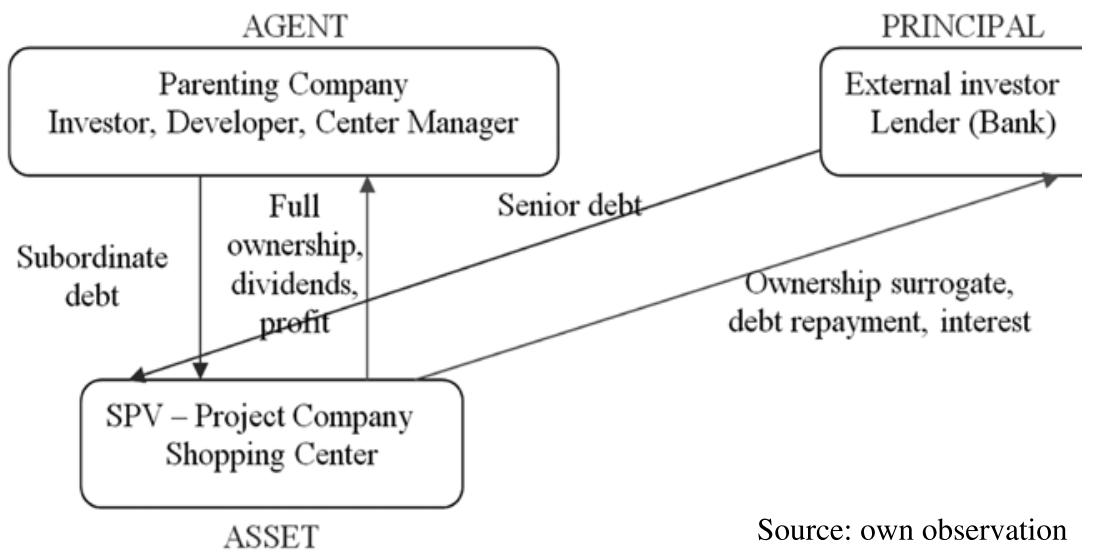

Principal-Agent Relationship when

distinct corporations (groups) play the role of investor, developer and center manager

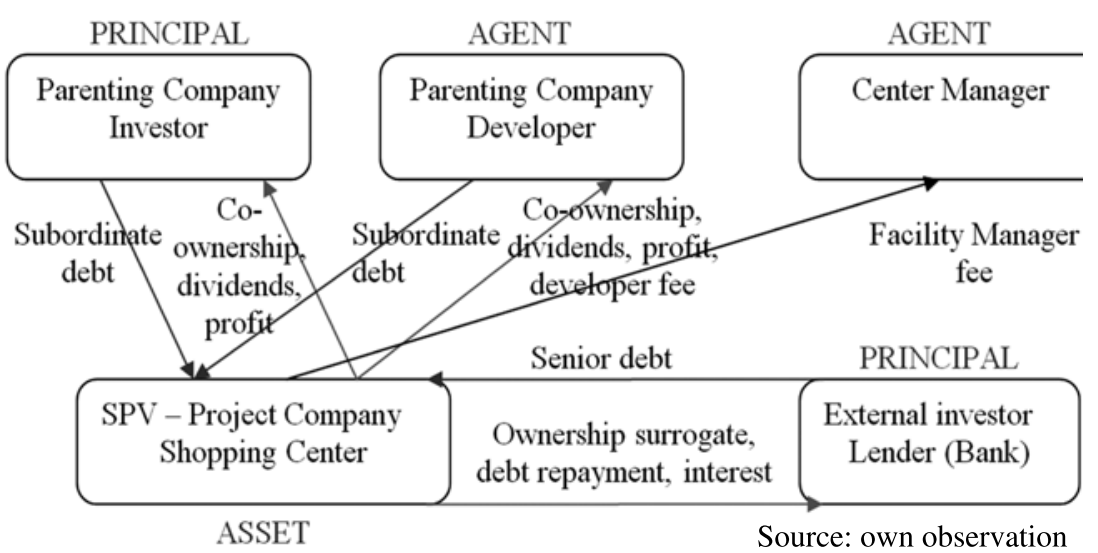

Principal-Agent Relationship when separate corporations (groups) play the role of developer and center manager, while both play the role of investors

\section{AGENT}

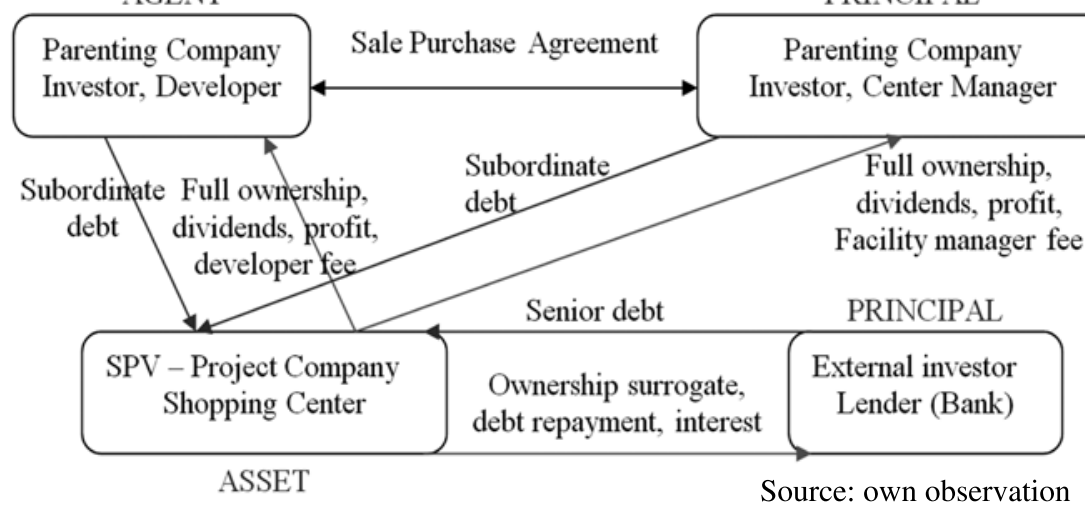

center's investors are banks (external investors), various investment funds or private investors. The developers create the shopping center using the capital of these investors, thus they should act in accordance with the interests of investors even if it means against their own interests. The situation is the same in case of center managers, as they should operate the respective shopping center as it were their own and should apply the most profitable and costeffective measures in order to achieve the expected returns for the investors.

In order to avoid conflicts of interest or the appearance of agency theory related problems, the optimal case is when the role of the investor, developer and facility manager is played by a single corporate group and when the financing is entirely own capital. But cases like this are very rare, they happen "once in a blue moon". Therefore, in the majority of cases the following three scenarios occur:

1. Scenario 1: the role of the investor, developer and center manager is played by one single corporate group, but for financing the shopping center foreign capital from various banks or other credit institutions are used in the form of long term loans. There is an external investor, credit institution, bringing a large amount of foreign capital, in the background as Principal (Table 2 and Figure 1).

2. Scenario 2: distinct corporations (groups) play the role of investors, developers and center managers. In these cases the ownership is at the investing parent company, which finances the required costs from their own capital as subordinate debt or mezzanine capital, sometimes together with a co-investor. An external investor is usually also present (Table 3 and Figure 2).

3. Scenario 3: separate corporations (groups) carry out the development activity and center management activity, while both play the role of investors. The characteristic of this 
structure is that ownership changes hands on short and medium-term. In the beginnings, during the development of the shopping center, the ownership is by the developer, who plays also the role of the investor, in most cases with the help of external investors who are financing the project with long term loans (Table 4 and Figure 3).

Beside these three basic relational structures, there are other relational, institutional variations as well, but these are the ones that appear the most. In these cases, we encounter different risk distribution ways, different occurrence of information asymmetry and different exercise of control.

\section{Agency Theory Related Problems in the Shopping Center Industry}

The above mentioned, most often met, institutional relationship structures lead to various agency theory problems like: risk sharing, moral hazard and adverse selection.

Risk sharing problem occurs for instance between the External Investor as Principal and the Investor-Developer as Agent described in Scenario 1. The debtto-equity ratio in a Project Company varies between $60-90 \%$ from the total investment of the respective shopping center. Therefore the Principal who offers financing based on a loan agreement in the form of senior debt is bearing the outmost part of the risks from the investment. In return, the Principal receives only an assurance that the mezzanine capital from the InvestorDeveloper as Agent will be considered a subordinate loan, and some ownership surrogates like mortgage on asset, on receivables, on the shares of the project company etc. Nevertheless, there is no warranty of a full repayment in case of insolvency or bankruptcy of the project company and/or in case of a serious depreciation in the shopping center's value. In such cases of failed investments, there is no equitable sharing of losses proportionately with the investment contribution, neither any security for the Principal or the Agent to cover all losses. Depending on the degree of the loss, it might happen that in absolute value, the Principal's loss is greater than the one of the Agent, due to the high debt-to-equity ratio. A similar risk sharing problem might occur also in case of Scenario 2. between the two parenting companies when the Investor as Principal have a senior debt over the subordinate debt of the Developer as Agent.

Moral hazard might appear in Scenario 2. between the Investor as Principal and the Developer as Agent. Although, both of them are co-investors and co-owners in the project company and both provide equity in the form of mezzanine capital, subordinate debt; the development works (planning, permitting, construction, leasing and opening) are performed exclusively by the Developer as Agent based on a development agreement and for which tasks the developer receives a development fee from the project company. In this case information asymmetry appears, as most of the market information relevant to the success of the shopping center is at the Developer as Agent, whose work can't be completely monitored by the Investor as Principal. The effects of moral hazard might be even deeper, in case of a forward purchase agreement between the Investor as Principal and the Developer as Agent for buying the Developer's shares from the project company for a fixed price at the completion of the shopping center. In this case the Developer is more tempted to act opportunistically and earn as much as possible during the development of the shopping center on the costs of the Investor. A similar situation of moral hazard might appear between the Investor as Principal and the Center Manager as Agent based on a management agreement. The outcome of such agreement is more predictable and measureable, while the tasks to be performed are also programmable, the Principal posses more tools to verify and control the behavior of the Agent; therefore the remuneration of the Agent is usually twofold, having a fixed part for the verifiable behavior and an outcome based bonus part.

Adverse selection suggests an opportunistic behavior before entering into a contract, thus a perfect example appears in Scenario 3. between the InvestorDeveloper as Agent and the Investor-Center Manager as Principal based on a sale purchase agreement to be concluded after completion of the shopping center. In this case the Agent bears the advantage of the Seller in comparison with the Buyer as Principal. Despite the fact that the Buyer carries out legal, financial and technical due diligences, it is still impossible to verify all aspects of the shopping center and project company. Therefore, in most of the cases the value of the shopping center or project company is overrated and the Principal pays a much higher transactional purchase price to the Agent instead of its fundamental value, while minimizing the transaction costs. After the sale-purchase is executed, it remains on the Principal's skills and abilities to maximize the profits of the project company as an Investor-Center Manager. Similar situations might occur in Scenario 2 between the Investor as Principal and the Developer or Center Manager as Agent. In case of Center Managers, whose work is highly programmable and the outcomes are measureable, the problems of adverse selection might be diminished with an appropriate 
contract structure. The Developers tasks are in contrast very complex and unforeseeable, un-measurable therefore adverse selection might be a considerable agency problem in their case. If Developers don't possess the required know-how, experience and contact capital for a successful shopping center development, they might cause significant harm and loss to the Investors, which might occur during development or after completion.

\section{Research questions and propositions}

This study focuses on how principal-agent problems influence the fall of shopping centers? It would be myopic to state that principal-agent problems are the only source of fall for shopping centers and to neglect the lacks in selecting the appropriate Location, in overestimating purchasing power and demand or in the failure of analyzing competition. The financial and economic crisis also accentuated the effects of these problem sources, especially since the industry of shopping centers is very capital demanding. Nevertheless, the focus here is on assessing the principal-agent problems within the context of the shopping center industry as a factor contributing to their fall. The main goal of the present article is to reveal agency theory related problems underlying the fall of shopping centers while finding the logic between the problems and the out-coming real-life solutions. Therefore we formulate the following propositions:

0 . Fall of shopping centers: There is a principalagent problem behind each shopping center fall as a contributing source, at least in the form of a risk sharing problem due to project financing.

1. Risk sharing: The lower debt-to-equity ratio within the project company, it has a positive effect on an equitable risk and loss sharing between the External Investor as Principal and the Investor-Developer as Agent.

2a. Moral hazard: The higher stake of the Developer as Agent in the investment has a positive effect on his behavior in avoiding opportunistic actions against the interests of the Investor as Principal.

2b. Moral hazard: An optimal trade-off between a behavior and outcome based management agreement reduces opportunistic behavior of the Center Manager as Agent, while minimizes transaction costs for the Investor as Principal.

3. Adverse selection: The higher the transaction costs for verifying the value of the to be purchased asset/project company the more likely to decrease the possibility of adverse selection.
4. Out-coming solutions: The out-coming solutions from the fall of shopping centers are initiated and often brought to an end by the Principal of the respective principal-agent problem.

The gathered available data will permit the analysis of the Propositions 0, 1, 2a., 3 and 4. The analysis of Proposition 2b. lies outside the scope of the present article.

\section{Research method}

In identifying the agency theory problems underneath the fall of shopping centers in Romania and to test the above formulated assumptions we'll use the qualitative research method of multiple-case studies. As Baxter Jack (2008: p. 548.) reflects ,,a multiple case study enables the researcher to explore differences within and between cases. The goal is to replicate findings across cases $[\ldots]$ or predict contrasting results based on a theory." The context of analysis is provided by the institutional background of failed shopping centers. As such we consider failed shopping centers, those centers which were/are undergone either an insolvency/bankruptcy/forced execution, got closed or were sold as distressed assets.

The units of analysis for these cases are the principal-agent problems within these contexts and the guiding conceptual framework for data analysis and interpretation is provided by the agency theory embedded in the field of shopping centers. The falls will be described in detail, including the actors involved in these cases and the principal-agent relationships between them. The data for the case studies have been gathered from objective secondary sources - mainly articles from on-line newspapers as outlined at the end of references - over a time period ca. 6 years, covering the time span from 2006 till 2012. The gathered data have been centralized in a smaller database shown in Table 5. Data analysis already started during the time of data collection using the following techniques: pattern matching, explanation building and cross-case synthesis (Yin, 2003).

\section{Data analysis: Cases and results}

As mentioned above the cases are gathered and organized in a small scale database, while each case is described in detail following the same structural guidelines in order to enable comparison between the cases and the identification of similarities and differences. The sequence of the cases are aligned in accordance with the 3 Scenarios described as different the Principal-Agent Relationships in the Shopping Center Industry. 


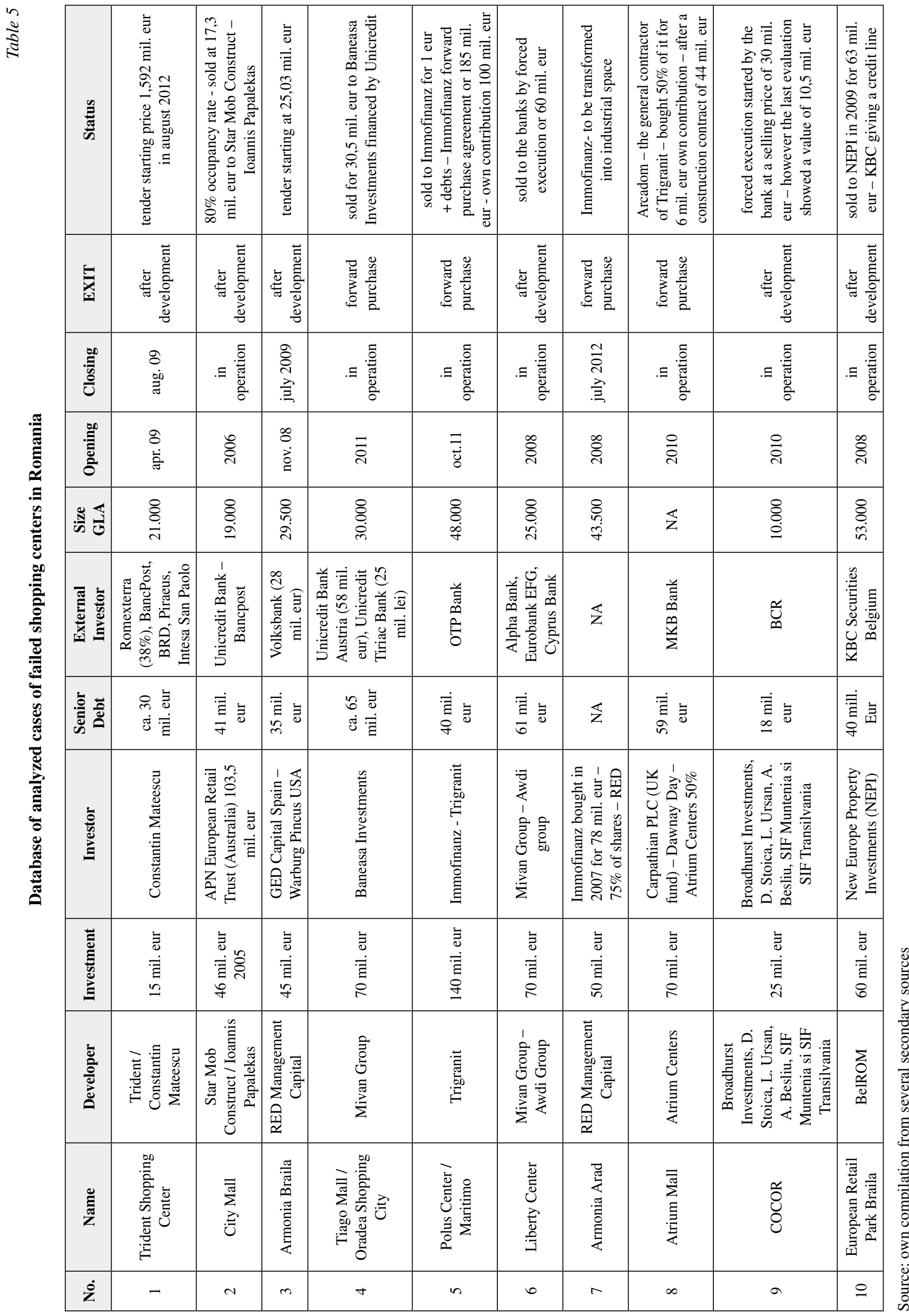


SCENARIO 1: the role of the investor, developer and center manager is played by one single corporate group.

Case 1: TRIDENT - in Sibiu has been developed by Trident Group led by a local investor. Trident Group operated a successful local chain of supermarkets, when decided to realize a shopping center in Sibiu with a Trident hypermarket as an anchor store. The center was completed in April 2009 having a gross leasable area of ca. 21.000 sq.m. after performing a total investment of 15 million euro. The Group as a whole has been using external financing up to a total value of 30 million euro provided by Romexterra (38\%), BancPost, BRD, Piraeus Bank and Intesa San Paolo. Unfortunately the expectations haven't met the actual results of the shopping center, thus the center has been closed in August 2009 and insolvency proceedings started against the whole group. As part of this proceeding, in August 2012, the center has been offered to sale under public tender for a starting price of 1,592 million euro.

Case 2: COCOR - located in the heart of Bucharest is the reconstruction of an old commercial center. The Investor-Owners (Broadhurst Investments, Daniel Stoica, Liviu Ursan, Aurel Besliu, SIF Muntenia and SIF Transilvania) as Agents contracted a loan of 18 million euro from the Romanian Commercial Bank (BCR), local subsidiary of ERSTE Group AG in order to carry out a complete center refurbishment which required a total investment of 25 million euro. Thus the debt-to-equity ratio of the investment was of ca. $72 \%$. The center has been fully leased and re-opened in 2010 and is since in operation, although the results showed weak turnover and lack of liquidity. Therefore, in 2012 BCR started forced execution proceeding against the project company at a starting price of 30 million euro. Some mistakes appeared in the legal proceeding and the difference between the reported estimated value ( 42 million euro) and the starting tender price (30 million euro) lead to the suspension of the procedure as no interested party showed up. In the meantime the project company transferred ca. 2 million euro to BCR starting the repayment of the senior debt.

SCENARIO 2: distinct corporations (groups) play the role of investors, developers and center managers.

Case 3: ARMONIA BRAILA - has been developed by RED Management Capital from a total investment of 45 million euro. The Investor and Co-owner was
GED Capital - Warburg Pincus. In order to secure the needed investment beside the mezzanine capital, a senior debt of 35 million euro has been contracted, out of which 28 million euro were provided by Volksbank. Therefore the debt-to-equity ratio within the project company was of $78 \%$. The shopping center with 29.500 sq.m. gross leasable area was opened in November 2008 having as anchor tenant a Carrefour hypermarket. The second phase of shopping gallery was lacking and not developed properly, therefore the hypermarket couldn't hold and Carrefour closed its store shortly after opening; by July 2009 the complete center has been locked for closure. The creditors attempted to sell the center in 2012 through a public tender with a starting price of 25,03 million euro with no success.

Case 4: POLUS CENTER CONSTANTA / MARIT$I M O$ - Polus Center Constanta was planned to be developed by the successful Hungarian real estate developer Trigranit. The total investment cost was estimated to 140 million euro. External financing was obtained from OTP Bank in the value of 40 million euro. The project company was in the coownership of Trigranit and an Austrian public listed investment fund called Immofinanz, who provided mezzanine capital and who also offered a forward purchase agreement at a fixed price of 185 million euro. During the development of the project, several problems appeared with the general contractor etc. and in 2010 Immofinanz decided to step in. Thus, he used his option to purchase the shares of the project company, but instead of the previously established purchase price, he paid 1 euro and assured OTP Bank to repay the senior debt. Subsequently the Investor-Principal took charge and completed the shopping center, which was opened in October 2011 and re-branded as Maritimo. It is in operation since then.

Case 5: ATRIUM ARAD - is the first project of the Hungarian Developer Atrium Centers in Romania. The project company was $50-50 \%$ in the ownership of Atrium Centers and Carpathian PLC - Dawnay Day a UK based Investment Fund. The total investment cost was estimated to 70 million euro, with external financing from MKB Bank in an amount of 59 million euro, thus reaching a debt-to equity ratio of $84 \%$. The Developer selected as General Contractor, the construction company of Trigranit Group, called Arcadom and granted him a construction contract of 44 million euro. In 2009, the UK listed Investment Fund, Carpathian PLC - Dawnay Day went broke, 
and Atrium was in need for a new Investor, a new partner. Finally shortly after completion and opening, in 2010, the General Contractor stepped in as new Investor and became 50\% owner of the project company agreeing to a purchase price of 6 million euro for the shares - probably through a set-off resulted from the general construction contract. The shopping center is since in operation.

Case 6: ARMONIA ARAD - has been developed by RED Management Capital with 43.500 sq.m. gross leasable area. The center opened in 2008 having Carrefour as anchor tenant and a shopping gallery. Immofinanz, the Investor and Co-owner signed a forward purchase agreement in 2007, committing him to pay 78 million euro for $75 \%$ of the SPV's shares, despite the fact that the total investment was estimated to 50 million euro. The difference of 28 million euro was sustained by a net present value (NPV) calculation with discounted cash flow estimation on a long term. The financial and economic crisis and the fierce competition affected the shopping center, which was closed in July 2012, shortly 5 years after its opening. The risk adverse behavior of the External Investor as Principal was a major contribution to this closure. Immofinanz is now planning to refurbish and reposition the shopping center as an industrial/logistic plant.

SCENARIO 3: separate corporations (groups) carry out the development activity and center management activity, while both play the role of investors.

Case 7: CITY MALL - The case of City Mall from Bucharest is the first and most famous failure of a shopping center in Romania. The center has been first bought by Star Mob Construct (Mr. Ioannis Papalekas) in 2005 for 46 million euro for the purpose of further development and Exit. Finally, the 19.000 sq.m. shopping center was opened in 2006 and shortly after sold to the Australian APN European Retail Trust for 103,5 million euro. The sale purchase agreement was financed by Unicredit Tiriac Bank and BancPost as External Investors with 41 million euro, reaching a debt-to-equity ratio of $39 \%$ from the total investment. The shopping center was in full operation since its opening and had an occupancy rate of at least $80 \%$, still the center went through insolvency proceeding beginning with 2009, and there were approx. 5 attempts to sell the shopping center through a public tender, which all failed due to lack of interested buyers. Finally in 2011, the former Developer, Mr. Ioannis Papalekas decided to buy back the center through direct negotiation for a purchase price of 17,3 million euro. The shopping center is since in operation and shall be repositioned as an office center.

\section{Case 8: TIAGO MALL / ORADEA SHOPPING CITY}

- Tiago Mall from Oradea is a shopping center started in 2007 by the Irish construction group Mivan. The total investment of the center was estimated to 70 million euro, which beside subordinate debt was secured by senior debt provided by Unicredit Bank Austria and Unicredit Tiriac Bank in the total amount of 65 million euro. The resulting debt-to-equity ratio was very high reaching $92 \%$ from the total investment. At the end of 2008 the developer failed to lease the shopping center. Thus, in the spring of 2009 the project company entered into insolvency and after several failed public tenders, finally in 2010 the center was bought by a company belonging to Baneasa Investments for 30,5 million euro. The acquisition was re-financed by Unicredit Bank Austria with some conditions on operating the shopping center. The new Investor-Principal rebranded the shopping center into Oradea Shopping City and leased it in approx. $40 \%$, so that the center could be opened in 2011, since which is in operation.

Case 9: LIBERTY CENTER - in Bucharest is the project of the Irish construction group Mivan developed in partnership with the Lebanese Awdi Group. They've started the development with the scope of selling it to an institutional investor after its completion. The total investment of the center was estimated to 70 million euro, for which external financing was obtained in the value of 61 million euro from external investors like Alpha Bank, Eurobank EFG and Cyprus Bank and thus reaching to a debt-to-equity ratio of $87 \%$. The shopping center with 25.000 sq.m. gross leasable area was opened in 2008 and is ever since in operation. As the senior debt felled due in 2012 and the project company proved to be unable to repay it, the banks decided to start forced execution and take control over the shopping center through a direct sale / set-off.

Case 10: EUROPEAN RETAIL PARK BRAILA - The European Retail Park in Braila has 53.000 sq.m. GLA and opened its gates in 2008 after the development of BelROM a Belgian developer. The total investment costs were estimated to 60 million euro, out of which 40 million was provided by KBC Securities from Belgium, resulting in a debt-to-equity ratio of $66 \%$. Shortly after completion, the center 
was sold as distressed asset to the South African public listed investment fund called New Europe Property Investment (NEPI) for 63 million euro, slightly above the estimated total investment cost. Nevertheless the transaction couldn't have been taking place, if the External Investor, KBC Securities wouldn't have been offering a credit line to finance beside this purchase also another project in a package deal.

\section{Overview of cases: pattern matching and cross-cases synthesis}

The cases of failed shopping centers in Romania during the period of 2006-2012 are described above in detail and grouped alongside their context of analysis, respectively based on the relational structures between the involved actors as formulated through the 3 Scenarios mentioned in the theoretical background. Regardless of the relational structure as distinct contexts, all of the cases showed signs of risk sharing related agency problems. Therefore this seems to be a general problem of the whole shopping center industry and is strictly related to project financing issues with the involvement of external investors, lenders and banks. In alignment with the expectations, the simpler the relational structures between the involved actors, the less agency problems arise. As a consequence, in cases of Scenario 1 (Trident, Cocor), where the Agent plays the role of the Developer, Center Manager and Investor in the same time, while there is an External Investor-Lender as Principal, the only agency problem which occur is risk sharing.

The more market actors are involved and the more complex is the relationship structure between them as described in Scenario 2 and Scenario 3, additional agency problems appear as moral hazard or adverse selection. Due to the low level of transactions during the analyzed period of 2006-2012 full of waves of default, moral hazard (5 cases: Armonia Braila, Polus Center/Maritimo, Atrium Arad, Tiago Mall/OSC, Liberty Center) appeared more frequently than adverse selection (4 cases: Armonia Arad, City Mall, Tiago Mall/OSC, European Retail Park Braila). In fact two of the discovered adverse selections in case of Armonia Arad and City Mall have roots before the crisis, in 2006; however, light shed on the problems only after the crisis. The ownership structure of the SPV, whether co-owned by the Developer (Armonia Braila, Polus Center/Maritimo, Atrium Arad) or fully owned by him (Tiago Mall/ OSC, Liberty Center), had no influence on the occurrence of moral hazard. Nor has the debt-to- equity ratio influence on the occurrence of risk sharing, as shopping centers with the lowest levels like Polus Center/Maritimo (29\%) and City Mall (39\%), as well as shopping centers with the highest levels like Tiago Mall/OSC (92\%) and Liberty Center (87\%) both suffered from risk sharing. Actually the highest loss of an External Investor was recorded in the case of Tiago Mall/OSC where Unicredit Bank Austria and Unicredit Tiriac Bank jointly lost 54\% of the senior debt, 29,5 million euro.

This shopping center seemed to be actually the only one where all agency problems occurred simultaneously: risk sharing with the lenders, moral hazard with the developer (Mivan Group) and adverse selection with the investor, Baneasa Investment who bought it through a public tender for 30,5 million euro and since then struggles to keep the center open. Nevertheless, the highest record of loss is registered in the case of City Mall, where by the adverse selection of the Investor APN European Retail Trust acquiring the mall for 103,5 million euro and re-selling it for 17,3 million euro, ultimately resulted in a loss of 86,2 million euro representing $83 \%$ from the total investment. With this City Mall registered itself in the history of failed shopping centers in Romania and is currently repositioned as an office center. Another interesting case of adverse selection is represented by the forward purchase of Armonia Arad by Immofinanz paying a 28 million surplus in addition to the development costs for acquiring the SPV. In five years from the purchase the center has been closed with the hope of repositioning as an industrial plant. Most of these agency problems came to light by the initiative of the lenders, banks starting to write off the non-performing loans (NPL's) or by one of the Co-owners and thus were started by a Principal and also solved by the same Principal (Polus Center/ Maritimo, Armonia Arad, Tiago Mall/OSC, Liberty Center, European Retail Park Braila). Three shopping centers: Trident, Cocor and Armonia Braila are in expectation of a solution, while City Mall and Atrium Arad represent odd-one-outs. In their cases the solutions came from the Agents, either in partnering against the fall-out of an investor (Atrium Arad) or by bringing developer know-how and experience in repositioning the facility (City Mall).

In general we could conclude that wherever moral hazard appeared, it was triggered by the lack of knowhow and experience of the involved Developers, while adverse selection occurred due to Investors trying to minimize transaction costs. Thus, each of these agency problems is strictly related to one category of involved actors: risk sharing problem is associated with lenders, 
Summary of results based on the tested propositions

\begin{tabular}{|c|c|c|c|c|c|}
\hline Shopping Center & $\begin{array}{c}\text { P0: } \\
\text { Principal-Agent } \\
\text { problem behind } \\
\text { of fall } \\
\end{array}$ & $\begin{array}{c}\text { P1: } \\
\text { Risk sharing: } \\
\text { debt-to-equity } \\
\text { ratio } \\
\end{array}$ & $\begin{array}{c}\text { P2a: } \\
\text { Moral Hazard: } \\
\text { stake of the } \\
\text { Developer } \\
\end{array}$ & $\begin{array}{c}\text { P3: } \\
\text { Adverse } \\
\text { Selection - } \\
\text { transaction costs } \\
\end{array}$ & $\begin{array}{c}\text { P4: } \\
\text { Outcoming } \\
\text { solutions: } \\
\text { Principal's role } \\
\end{array}$ \\
\hline Trident & Risk Sharing & NA & - & - & $\begin{array}{c}\text { Initiated by the } \\
\text { Principal }\end{array}$ \\
\hline Cocor & Risk Sharing & $72 \%$ & - & - & $\begin{array}{c}\text { Initiated by the } \\
\text { Principal }\end{array}$ \\
\hline Armonia Braila & $\begin{array}{c}\text { Moral Hazard } \\
\text { Risk Sharing }\end{array}$ & $78 \%$ & Co-ownership & - & $\begin{array}{c}\text { Initiated by the } \\
\text { Principal }\end{array}$ \\
\hline $\begin{array}{c}\text { Polus Center/ } \\
\text { Maritimo }\end{array}$ & $\begin{array}{l}\text { Moral Hazard } \\
\text { Risk Sharing }\end{array}$ & $29 \%$ & Co-ownership & - & $\begin{array}{c}\text { Initiated and solved } \\
\text { by the Principal }\end{array}$ \\
\hline Atrium Arad & $\begin{array}{l}\text { Moral Hazard } \\
\text { Risk Sharing }\end{array}$ & $84 \%$ & Co-ownership & - & $\begin{array}{c}\text { Initiated by the } \\
\text { Principal but solved } \\
\text { by the Agent }\end{array}$ \\
\hline Armonia Arad & $\begin{array}{l}\text { Adverse Selection } \\
\text { Risk Sharing }\end{array}$ & NA & - & $\begin{array}{l}\text { Forward purchase } \\
\text { agreement - low } \\
\text { transaction costs }\end{array}$ & $\begin{array}{l}\text { Initiated and solved } \\
\text { by the Principal }\end{array}$ \\
\hline City Mall & $\begin{array}{l}\text { Adverse Selection } \\
\text { Risk Sharing }\end{array}$ & $39 \%$ & - & $\begin{array}{l}\text { In } 2006 \text { direct sale } \\
\text { - low transaction } \\
\text { costs }\end{array}$ & $\begin{array}{c}\text { Initiated by the } \\
\text { Principal and solved } \\
\text { by the Agent }\end{array}$ \\
\hline Tiago Mall/ OSC & $\begin{array}{c}\text { Moral Hazard } \\
\text { Risk Sharing } \\
\text { Adverse selection }\end{array}$ & $92 \%$ & Full ownership & $\begin{array}{c}\text { Bankruptcy } \\
\text { proceedings, } \\
\text { public tender-high } \\
\text { transaction costs }\end{array}$ & $\begin{array}{l}\text { Initiated and solved } \\
\text { by the Principal }\end{array}$ \\
\hline Liberty Center & $\begin{array}{l}\text { Moral Hazard } \\
\text { Risk Sharing }\end{array}$ & $87 \%$ & Full ownership & - & $\begin{array}{c}\text { Initiated and solved } \\
\text { by the Principal }\end{array}$ \\
\hline $\begin{array}{l}\text { European Retail } \\
\text { Park Braila }\end{array}$ & $\begin{array}{c}\text { Adverse Selection } \\
\text { Risk Sharing }\end{array}$ & $66 \%$ & - & $\begin{array}{l}\text { After completion } \\
\text { sale as distressed } \\
\text { asset - low } \\
\text { transaction costs }\end{array}$ & $\begin{array}{l}\text { Initiated and solved } \\
\text { by Principals }\end{array}$ \\
\hline RESULT & ACCEPTED & REJECTED & REJECTED & ACCEPTED & $\begin{array}{l}\text { PARTIALLY } \\
\text { ACCEPTED }\end{array}$ \\
\hline
\end{tabular}

Source: own compilation

moral hazard with developers and adverse selection with investors. The solutions to these problems however depend much more on the lenders and investors as Principals, than on developers as Agents.

\section{Results on propositions}

Having presented all of these cases in detail and while conducting a cross-cases synthesis we can go back to test our propositions. Table 6 . contains the summary of the results drawn from the analyses based on the testable propositions.

It turns out, that Risk Sharing remains the most serious agency theory related problem in the industry of shopping centers - being an underlying problem in all shopping centers failures. Therefore, proposition 0 should be accepted. Risk and loss sharing between the Developer-Agent and the Lender-Principal is never equitable. Although in some of the cases the lower debtto-equity ratio has a positive effect on loss sharing, the proposition 1 can't be accepted, nor generalized as for instance in case of City Mall with the lowest debt-toequity ratio of 39\%, the Investor lost everything, while the Lenders recovered less than half of the senior debt. Neither can we accept proposition $2 a$, since regardless of the stake of the Developer (full ownership in cases of Scenario 3 - or only co-ownership in cases of Scenario 2), the losses suffered by the Developers are considerable. Perhaps a better assessment of these losses as a result of moral hazard could be reached by substitut- 
ing the stake of the developer with his know-how and experience. Proposition $2 b$, as mentioned previously wasn't subject of analysis. Most of the ownership transfers occurring as solutions to failed shopping centers were undertaken either through public tender or forced execution. These represent high transaction costs in comparison to direct sales or forward purchase agreements. Thus proposition 3 should be accepted. The fall of shopping centers is in all cases initiated by either the Lender-Principal or by the Investor-Principal. Nevertheless we've encountered cases when the solution was found by the Developer-Agent like in case of Atrium Arad or City Mall from Bucharest. Therefore proposition 4 should be only partially accepted, as the problem is discovered and the solution initiated by the Principals, but the ultimate solution might come also from the Agents. In summary from the total of six propositions, we've accepted two (Proposition 0 and 3), rejected two (Proposition 1 and 2a), partially accepted one (Proposition 4) and haven't tested one (Proposition 2b).

Although, we haven't used several sources for data collection in order to assure triangulation through multiple viewpoints, but having in mind that multiple-cases studies have been used as research method, the results could be considered robust and reliable. The reliability in the phase of data collection was assured through the review of a multitude of news articles related to each given shopping center. Reliability of the findings is further enhanced by the fact that the analyzed cases represent $100 \%$ of the failed shopping centers in Romania during the studied time period of 2006-2012. Nevertheless, in Romania the total number of existing shopping centers, retail parks and outlet centers is of 139 (RegioData, 2012), which means that the analyzed cases would be equal with a sample of $7 \%$ from the total units. Due to the high degree of complexity of these contexts, each shopping center project might be the result of different principal-agent relationship construct; therefore it is questionable whether the results have validity also in different constructs and settings.

\section{Conclusions and recommendations}

The present article assesses agency theory problems contributing to the fall of shopping centers in Romania. In this view 10 failed shopping centers were selected and analyzed in detail in the form of multiple-cases studies. The theoretical background for the analysis is given by the positivist agency theory perspective applied to the institutional background of the shopping center industry. One of the main contributions of the paper is the formulation of the theoretical framework focused on the principal-agent relationships and problems within the shopping center industry. This is a novelty as studies thus far focused on agency problems only on the housing market (Levitt - Syverson, 2008), on public-private projects (Lyonnet du Moutier, 2010) or simply between borrowers and lenders (Allen Gale, 2000), shareholders and portfolio managers (Allen - Gorton, 1993) or within banks (Mishkin, 1997; Acharya - Naqvi, 2012).

Nevertheless, the empirical research focusing on micro-level multiple cases also offers interesting insights in the shopping center industry itself and its institutional-organizational structure. Results suggests that agency theory problems indeed contribute to the fall of shopping centers, at least in the form of risk sharing, which appeared in all cases, due to project financing and SPV's specifications, which is in line with Jensen (1983) and Allen - Gale (2000). Another interesting result is the fact that in this risk sharing cases, the External Investor, Lender as Principal acts the most risk neutral and impatient instead of the Developer as Agent or Investor as Principal; as a consequence he is the one who initiates in most of the cases a solution to the falling of the shopping center. This finding is in contrast with Watanabe (2010) suggesting that banks engage in evergreening in case of large losses of capital, which might suggest that banks use evergreening only on short term, as buffer, in order to assure in parallel a stable writing-off of NPL's. The most of risks and losses are bared in all of the cases by the Developer as Agent or the Investor as Principal. This would call for a careful selection of External Investors, Lenders in the early development stage of the shopping center, which should be based on trust and long term relationship. Surprisingly and in contrast with the expectations, Moral Hazard problems seem to appear not because of the low level of the Developer-Agent's stake as suggested by Jensen - Meckling (1976), but because of the lack of know-how and experience in the field of shopping centers.

This should stay as warning for self-appointed speculative Developers with no experience and lack of know-how. Adverse selection is nearly inevitable in case of forward purchase agreements and very probable in case of direct sales, even in case of distressed assets. The higher the transaction costs through bankruptcy proceedings, public tender or forced execution, the less likely to face adverse selection during ownership change. The solutions to the failure of the shopping centers are in all of the cases initiated by a Principal, although sometimes ultimately solved by an Agent. All these findings reflect a high degree of diver- 
sity depending on the contextual setting, institutionalorganizational background behind each shopping center. Thus, the validity and generalization of results is questionable, even though reliability is assured by the research method of multiple-cases studies. Therefore further research should focus on assessing agency theory problems in different settings, for example in different countries like India, where the financing of these projects relies much more on opportunistic behavior, attracting funds from speculators by selling prior completion some parts of the shopping center (Singh et al, 2009). Still, the novelty of the topic in the shopping center industry and the empirical evidences with solutions confer a significant academic and practical value for the present article.

\section{References}

Acharya, V.-Naqvi, H. (2012): The seeds of a crisis: A theory of bank liquidity and risk taking over the business cycle. Journal of Financial Economics, 106(2): p. 349-366.

Allen, F. - Gorton, G. (1993): Churning Bubbles. Review of Economic Studies, 60: p. 813-836.

Allen, F. - Gale, D. (2000): Bubbles and Crises. The Economic Journal, 110(1): p. 236-255.

Argawal, A. - Mandelker, G. (1987): Managerial incentives and corporate investment and financing decisions. Journal of Finance, 42(4): p. 823-837.

Baxter, P. - Jack, S. (2008): Qualitative case study methodology: Study design and implementation for novice researchers. The Qualitative Report, 13(4): p. 544-559.

Burr, S.I. (2011): The Practitioner's Corner: Buying and Selling Distressed Commercial Mortgage and Commercial Real Estate Assets; Whither Will Rating Agencies Go ? Real Estate Finance 28(1): p. 7-11.

Cocconcelli, L. - Medda, F.R. (2013): Boom and bust in the Estonian real estate market and the role of land tax as a buffer. Land Use Policy, 30(1): p. 392-400.

Ebrahim, S.M. - Mathur, I. (2013): On the efficiency of the UPREIT organizational form: Implications for the subprime crisis and CDO's. Journal of Economic Behavior - Organization, 85(1): p. 286-305.

Eisenhardt, K.M. (1989): Agency Theory: An Assessment and Review. The Academy of Management Review, 14(1): p. 57-74.

Fama, E. (1980): Agency problems and the theory of the firm. Journal of Political Economy, 88(2): p. 288-307.

Fenning, S.F. - Blazejack, J.A. - Mann, G.R. (2011): Price versus Fundamentals - From Bubbles to Distressed Markets. The Appraisal Journal, 79(2): p. 143-154.

Flaskár A. (2011): A franchise-szervezetek értelmezése a tulajdonosi jogok elmélete és az ügynökelmélet keretében. Vezetéstudomány, 42(9): p. 40-52.
Golob, K. - Bastic, M. - Psunder, I. (2012): Analysis of Impact Factors on the Real Estate Market: Case Slovenia. Inzinerine Ekonomika-Engineering Economics, 23(4): p. 357-367.

Jensen, C.F. (1983): The Use of Corporations in Real Estate Transactions: Judicial Acceptance of the Agency Theory. The Journal of Corporation Law, 8(2): p. 361-387.

Jensen, M. - Meckling, W. (1976): Theory of the firm: Managerial behaviour, agency costs, and ownership structure. Journal of Financial Economics, 3: p. 305360.

Kim, J. - Mahoney, J.T. (2005): Property Rights Theory, Transaction Costs Theory and Agency Theory: An Organizational Economics Approach to Strategic Management. Managerial and Decision Economics, 26: p. 223-242.

Levitt, S.D. - Syverson, C. (2008): Market Distortions when Agents are better Informed: The Value of Information in Real Estate Transactions. The Review of Economics and Statistics, 90(4): p. 599-611.

Lyonnet du Moutier, M. (2010): Financing the Eiffel Tower: Project Finance and Agency Theory. Journal of Applied Finance, 20(1): p. 127-141.

Podrug, N. - Filipovic, D. - Milic, S. (2010): Critical Overview of Agency Theory. Annals of DAAAM for 2010 - Proceedings of the $21^{\text {st }}$ International DAAAM Symposium, 21(1): p. 1227-1228.

RegioData (2012): RegioData Shopping Center Explorer Romania - Factsheet. Vienna: RegioData Research GmbH http://www.retailcenters.eu/system/files/private/ RegioData_Factsheet_RO_2012.pdf

Shah, S. - Thakor, A. (1987): Optimal Capital Structure and Project Financing. Journal of Economic Theory, 42(2): p. 209-243.

Singh, H. - Bose, S.K. - Sahay, V. (2009): Management of Indian shopping malls: Impact of the pattern of financing. Journal of Retail - Leisure Property, 9(1): p. 55-64.

Sliupas, R. - Simanaviciene, Z. (2010): The effect of real estate speculation on the growth of economics in transition countries. Economics and Management, 15: p. 295-301.

Watanabe, W. (2010): Does a large loss of bank capital cause Evergreening ? Evidence from Japan. Journal of the Japanese and International Economies, 24(1): p. 116136.

Wheelock, W.H. (1931): The Effect of the Present Financial Situation upon Real Estate. Harvard Business Review, 9(3): p. 311-318.

Williamson, O.E. (1991): Comparative economic organization: the analysis of discrete structural alternatives. Administrative Science Quarterly, 36: p. 269-296.

Yin, R. K. (2003): Case study research: Design and methods ( $3^{\text {rd }}$ ed.). Thousand Oaks, CA.: Sage 


\section{On-line sources for data collection on the cases, all reviewed on 08.12 . 2012:}

1. http://www.capital.ro/detalii-articole/stiri/trigranit-isiamana-planurile-din-romania-dupa-ce-si-a-renegociatcreditele-125134.html

2. http://www.businesscover.ro/28-10-2011-maritimo-shoppingcenter-mallul-de-un-euro-al-immofinanz-se-deschide-azi/

3. http://www.dailybusiness.ro/stiri-real-estate/constructorulmall-ului-din-arad-a-cumparat-jumatate-de-proiect-cu-o-ziinainte-de-inaugurare-40312/

4. http://www.wall-street.ro/slideshow/Real-Estate/82568/ Ce-urmeaza-dupa-vanzarea-a-50-din-Atrium-Center-Arad.html

5. http://www.ared.ro/logisticparc/index.php?lng=en-pag=stiristire_id=95-immoeast-deschide-mall-ul-armonia-in-arad-lasfarsitul-lunii-mai

6. http://www.cijjournal.com/immofinanz-closes-armonia-arad/

7. http://www.zf.ro/business-construct/immoeast-preia-centrulcomercial-armonia-arad-3063555/

8. http://www.curierulnational.ro/Actualitate $\% 2$

Companii/2008-05-28/Aradul+are+mall+de+50+de+milioan e+de+euro

9. http://www.wall-street.ro/articol/Real-Estate/72708/Toamnase-numara-tranzactiile-NEPI-da-63-mil-euro-pentru-un-parccomercial-din-Braila.html

10. http://realestate.doingbusiness.ro/ro/news/news_item. php?newsid=1721

11. http://www.doingbusiness.ro/ro/stiri-afaceri/13786/europeanretail-park-braila-a-fost-preluat-in-urma-unei-tranzactii-de-63milioane-euro
12. http://www.capital.ro/detalii-articole/stiri/tranzactieimobiliara-de-63-mil-euro-la-braila-126069.html

13. http://www.incomemagazine.ro/articol_81742/lichidatorulbdo-a-vandut-primul-spatiu-al-falimentarului-trident-afladetalii.html?action=print

14. http://www.capital.ro/detalii-articole/stiri/inca-un-mall-dinbucuresti-a-fost-scos-la-licitatii-169158.html

15. http://www.zf.ro/proprietati/liberty-center-a-fost-vandut-intrun-dosar-de-executare-silita-pretul-de-pornire-era-de-60-mileuro-cumparator-bancile-creditoare-9928288

16. http://www.incomemagazine.ro/articol_85979/cocor-a-scapatpentru-moment-de-vanzarea-prin-licitatie-impusa-de-bcr.html

17. http://www.wall-street.ro/articol/Real-Estate/91117/Baniipentru-Tiago-Mall-Oradea-au-fost-virati-Finantarea-vine-totde-la-UniCredit.html

18. http://media.imopedia.ro/stiri-imobiliare/armonia-braila-peurmele-city-mall-a-treia-licitatie-si-nimeni-nu-vrea-sa-dea-25mil-euro-pe-el-19378.html

19. http://ziuadecj.realitatea.net/economie/au-adus-la-cluj-350-demilioane-de-euro-40852.html

20. http://www.sibiul.ro/stiri-locale/belrom-a-deschis-galaxiamagazinelor-media-galaxy/7859/

21. http://www.wall-street.ro/articol/Real-Estate/111706/CityMall-vandut-pentru-17-3-mil-euro-Banii-merg-la-bancaproprietarul-nu-primeste-nimic.htm

Article provided: 2012. 12.

Article accepted: 2013. 2.

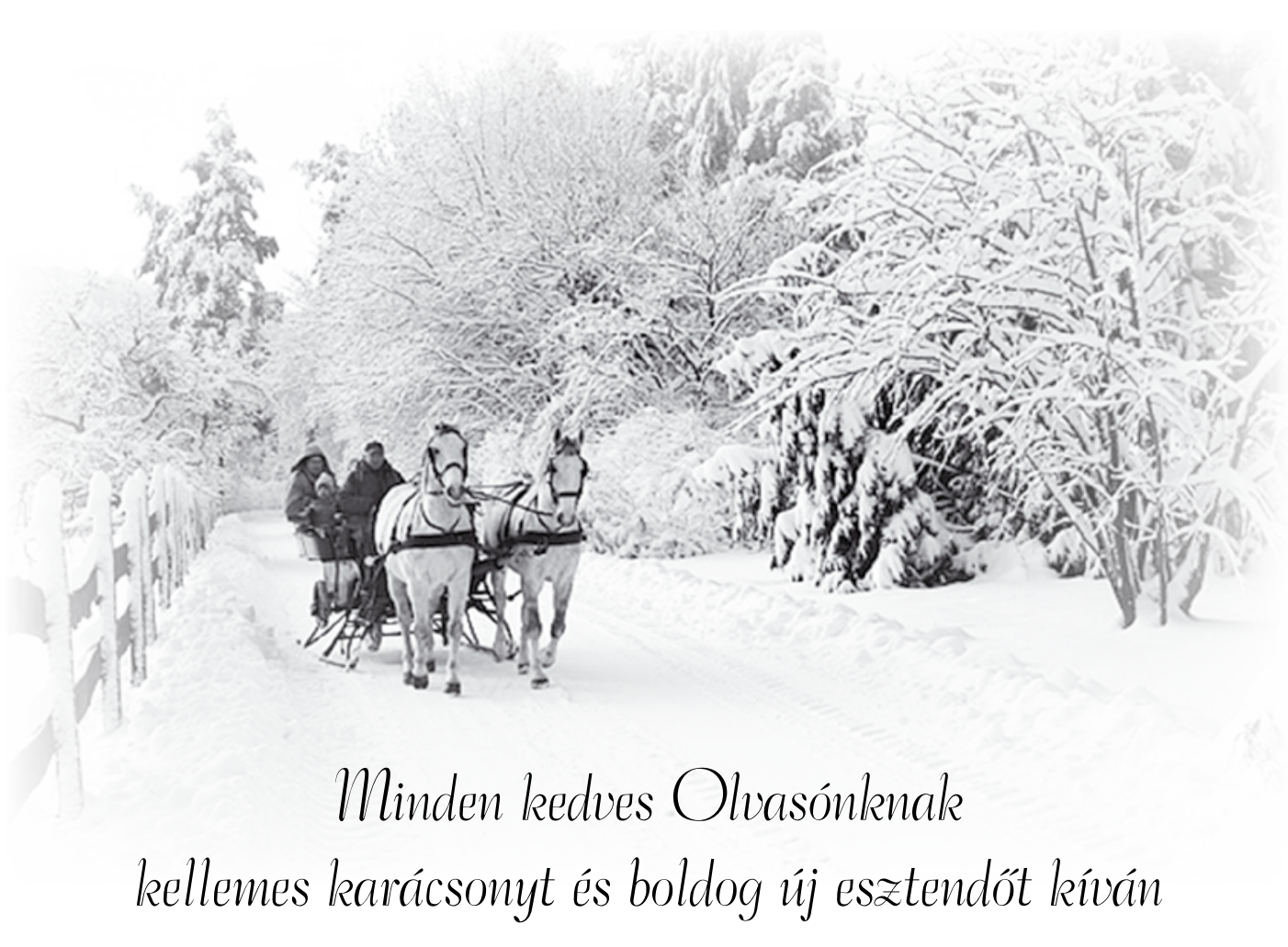

a Szerkesztőség

VEZETÉSTUDOMÁNY 